\title{
EVALUASI PENERAPAN AUTOMATIC EXCHANGE OF INFORMATION (STUDI BANDING INDONESIA DAN JEPANG) (EVALUATION OF AUTOMATIC EXCHANGE OF INFORMATION IMPLEMENTATION
} (BENCHMARK: INDONESIA DAN JEPANG)

\author{
Indriani, M. A. Vishu Juwono, Henderi Gunadi* \\ *Fakultas Ilmu Administrasi, Universitas Indonesia, Jl. Margonda Raya, Pondok Cina, \\ Kecamatan Beji, Kota Depok, indri4mf@gmail.com \\ *Fakultas Ilmu Administrasi, Universitas Indonesia, Jl. Margonda Raya, Pondok Cina, \\ Kecamatan Beji, Kota Depok, vjuwono@ui.ac.id. \\ *Direktorat Jendral Pajak, Jl. Gatot Subroto, henderi.dgt@gmail.com
}

\begin{abstract}
The implementation of Automatic Exchange of Information (AEoI) has entered its third year, Indonesia and Japan have become one of the countries that implement AEoI simultaneously in international agreements. This study was conducted to explain, analyze and find out related to the evaluation of AEOI policies that have been carried out in Indonesia and Japan in the audit process to explore potential tax revenues, this research was conducted using a qualitative approach and data collection techniques through indepth interviews and literature studies. The results of this study indicate that the implementation of the AEoI policy in Indonesia is good, although there are still obstacles related to the incompleteness of data resulting from the automatic exchange of information obtained through financial institutions, while in Japan this has been successful, this is supported by high tax compliance by taxpayers in Japan, the use of single identity number, the system that has been built, and the standard that has been set.
\end{abstract}

Keywords: Automatic Exchange of Information, AEoI Evaluation, Tax Potential, Tax Audit

\begin{abstract}
Abstrak
Penerapan Automatic Exhange of Information (AEoI) telah memasuki tahun ketiga, Indonesia dan Jepang telah menjadi salah negara yang mengimplementasikan AEoI secara bersamaan dalam perjanjian internasional. Penelitian ini dilakukan untuk menjelaskan, menganalisis dan mengetahui terkait evaluasi kebijakan AEoI yang telah dilakukan di Indonesia dan Jepang dalam proses pemeriksaan untuk penggalian potensi penerimaan pajak, penelitian ini dilakukan dengan menggunakan pendekatan kualitatif dan teknik pengumpulan data melalui wawancara mendalam dan studi literatur. Hasil penelitian ini menunjukkan bahwa implementasi kebijakan AEoI di Indonesia sudah baik walaupun masih terdapat kendala terkait ketidaklengkapan data hasil pertukaran informasi secara otomatis yang didapatkan melalui lembaga keuangan sedangkan di Jepang sudah berhasil hal ini didukung oleh kepatuhan pajak yang tinggi oleh wajib pajak di Jepang, penggunaan single identity number, sistem yang telah terbangun, dan standar yang telah ditetapkan. Kata Kunci : Automatic Exchange of Information, Evaluasi AEoI, Potensi Pajak, Pemeriksaan Pajak
\end{abstract}




\section{LATAR BELAKANG MASALAH}

OECD telah mengembangkan Common Reporting Standard (selanjutnya disebut CRS) sebagai tanggapan permintaan G20. CRS ini menetapkan informasi keuangan yang akan dipertukarkan dan dilaporkan yang bersifat wajib oleh lembaga keuangan. CRS merupakan panduan untuk negara-negara yang mengikuti pertukaran informasi secara otomatis CRS yang telah dijealaskan oleh OECD dalam handbook Standard for Automatic Exchange of Financial Account Information in Tax Matters. Peraturan terkait keterbukaan data ini untuk kepentingan DJP dalam hal menguatkan basis data pajak mengingat Indonesia menerapakan self assessment system dalam hal WP melakukan kewajiban perpajakan. Data dan informasi sangat penting bagi DJP untuk melakukan pengawasan dalam pelaksanaan kewajiban perpajakan sebagai konsekuensi penerapan sistem SAS. Ketersediaan data menjadi penting apabila sedang dilakukan pemeriksaan, penagihan pajak, atau penyidikan tindak pidana di bidang perpajakan terhadap wajib pajak.

Sebelum adanya Automatic Exchange of Information (AEoI), kewenangan DJP dalam hal memperoleh data memiliki keterbatasan karena DJP hanya bisa mendapatkan akses keterbukaan data informasi keuangan dengan tujuan pemeriksaan, penagihan, dan penyidikan, artinya selain tujuan tersebut DJP tidak memiliki wewenang lebih untuk mendapatkan akses keterbukaan data. Keterbukaan data ini sangat penting bagi DJP untuk dapat mengoptimalkan penerimaan pajak dimana hal ini secara tidak langsung dapat berdampak juga untuk kepentingan pemerintah dalam belanja pemerintah, seperti pembangunan infrastruktur, pembangunan sumber daya manusia berkelanjutan, dan penguatan desentralisasi fiskal. Keterbatasan yang dimiliki DJP menjadi salah satu hambatan dalam memenuhi kebutuhan penerimaan pajak, DJP perlu memiliki keleluasaan dalam mengakses data untuk kepentingan perpajakan. DJP perlu mendapatkan kepercayaan untuk memiliki pusat data nasional dalam hal kepentingan perpajakan dengan diberikan keterbukaan akses data yang luas.

Akses keterbukaan data yang luas bagi DJP diperoleh pada tahun 2018, setelah Indonesia mengikuti dan menandatangani perjanjian internasional di bidang perpajakan dengan negara-negara lain yang tergabung dalam G-20, hal ini mewajibkan Indonesia untuk memenuhi pertukaran data secara otomatis untuk kepentingan perpajakan. Sebelum adanya keterbukaan data secara otomatis ini, pada ranah internasional pertukaran informasi sudah diatur dalam model acuan OECD pada Tax Treaty Article 26 tentang Exchange of Information bagi negara-negara yang memiliki Tax Treaty dengan treaty partner Indonesia yang telah menandatangi perjanjian internasional, artinya Indonesia telah mengikat diri pada perjanjian Internasional di bidang perpajakan yang berkewajiban untuk memenuhi komitmen keikutsertaan dalam mengimplementasikan pertukaran informasi keuangan secara otomatis dan harus segera membentuk peraturan perundangundangan setingkat undang-undang mengenai akses informasi keuangan untuk kepentingan perpajakan.

Oleh karena itu untuk menunjukan komitmennya, Pemerintah Indonesia menerbitkan Undang-Undang No 9 Tahun 2017 mengenai Akses Informasi Keuangan untuk Kepentingan Perpajakan dalam rangka memberikan kewenangan yang lebih luas kepada DJP untuk mendapatkan dan memperoleh akses informasi keuangan, dalam rangka pelaksanaan ketentuan peraturan perundang-undangan di bidang perpajakan dan pelaksanaan perjanjian internasional di bidang perpajakan. Kebijakan ini memiliki implikasi dimana DJP memiliki wewenang mendapatkan akses informasi keuangan untuk kepentingan perpajakan dari lembaga jasa keuangan yang melaksanakan kegiatan di sektor perbankan, pasar modal, perasuransian, lembaga jasa keaungan lainnya, dan/atau 
entitas lain yang dikategorikan sebagai lembaga keaangan sesuai dengan perjanjian internasional. Informasi yang dipertukarkan didalam AEoI salah satunya yakni saldo atau nilai rekening keuangan dan polis asuransi.

Akses DJP untuk memperoleh data informasi keuangan dari Lembaga Jasa Keuangan tidak bertentangan dengan kerahasiaan bank untuk nasabah, namun informasi yang diberikan memiliki keterbatasan DJP dimana hanya dapat memperoleh akses informasi untuk 3 (tiga) tujuan, yaitu pemeriksaan, penagihan, dan penyidikan dibidang perpajakan. AEoI merupakan program pertukaran informasi keuangan terkait pajak yang dilakukan secara berkala, otomatis, dan menyeluruh. Informasi keuangan yang dikirim adalah milik warga asing yang menetap di satu negara dan dikirim kepada otoritas pajak negara asal warga tersebut (Akmam, 2017). Kebijakan AEoI bisa menjadi salah satu upaya DJP untuk merespons kecepatan perubahan strategi bisnis dalam era digitalisasi ekonomi, sehingga bisa mengoptimalkan penerimaan pajak. Implementasi AEoI di Indonesia sudah berlangsung dari September 2018 dan sudah dipersiapkan oleh Kemenkeu beserta DJP sejak Indonesia mengikuti dan tergabung dalam Global Forum on Transparency and Exchange of Information. Salah satu bukti persiapan dari AEoI, Pemerintah telah mengeluarkan regulasi untuk Indonesia komitmen dalam implementasi AeoI yang diatur dalam Undang-Undang No. 9 Tahun 2017 mengenai Akses Informasi Keuangan Untuk Kepentingan Perpajakan.

Pertukaran data secara otomatis diharapkan dapat menggali potensi pajak dengan mencegah penghindaran pajak yang dilakukan oleh Wajib Pajak dan mendapatkan informasi keuangan untuk mempermudah melacak potensi pajak yang dapat dipungut. Lembaga Jasa Keuangan (LJK) yang sudah mendaftarkan pada awal 2018 telah mencapai 3.719 yang kemungkinan saat ini jumlahnya telah bertambah menjadi sekitar 8000, dimana hal ini menjadi bukti bahwa Indoensia berkomitmen atas perjanjian internasional yang telah ditandatangani dalam rangka pertukaran informasi untuk kepentingan perpajakan. Berdasarkan data OECD dalam implementation report of AEoI 2018, Indonesia telah melakukan pertukaran informasi keuangan dengan 57 negara, artinya DJP telah memiliki banyak informasi keuangan untuk mengoptimalkan penerimaan pajak karena pengoptimalan program AEoI oleh pemerintah dapat membuat DJP mendapatkan data untuk dilakukan analisis sebagai potensi penerimaan pajak. Oleh karena itu, hal ini yang kemudian menjadi perhatian peneliti mengenai evaluasi selama 3 tahun berjalan di Indonesia untuk menggali potensi penerimaan pajak. Disamping indonesia, Jepang juga menerapkan AEOI bersamaan dengan Indonesia pada gelombang kedua di tahun 2018, studi banding (benchmarking) dengan Jepang dilakukan karena kesamaan karakteristik yang dimiliki.

\section{POKOK PERMASALAHAN}

Kebijakan AEoI bisa menjadi salah satu upaya DJP untuk merespons kecepatan perubahan strategi bisnis dalam era digitalisasi ekonomi, sehingga bisa mengoptimalkan penerimaan pajak, mengingat penerimaan pajak tidak tercapat dalam 5 (lima) tahun terakhir. AEoI telah diimplementasikan di Indonesia sejak September 2018 dan diharapkan dapat menggali potensi pajak dengan mencegah penghindaran pajak yang dilakukan oleh Wajib Pajak dan mendapatkan informasi keuangan untuk mempermudah melacak potensi pajak yang dapat dipungut. Pertukaran data secara otomatis juga membantu untuk menghindari terjadinya praktik-praktik penghindaran pajak, karena data milik wajib pajak akan langsung dipertukarkan dengan negara mitra tanpa harus melalui proses permohonan sehingga pemerintah indonesia memiliki basis data terhadap seluruh wajib pajaknya yang menempatkan dana dan asset keuangan di luar negeri. Hal ini yang menjadi perhatian peneliti mengenai evaluasi AEoI yang selama tiga tahun berjalan di 
Indonesia, sehingga tujuan dari penelitian ini ialah sebagai berikut:

1. Memberikan gambaran evaluasi atas pelaksanaan Automatic Exchange of Information dalam Pemeriksaan Pajak di Indonesia.

2. Memberikan gambaran evaluasi atas pelaksanaan Automatic Exchange of Information dalam Pemeriksaan Pajak di Jepang.

\section{KERANGKA TEORI}

\section{Automatic Exchange of Information}

Automatic Exchange of Information (AEoI) merupakan program pertukaran informasi keuangan terkait pajak, dilakukan secara berkala, otomatis, dan menyeluruh. Informasi keuangan yang dikirim adalah milik warga asing yang menetap di satu negara dan dikirim kepada otoritas pajak negara asal warga tersebut (Akmam, 2017). Indonesia telah menjalin kerja sama dengan 103 negara mitra partisipan AEoI dan 85 negara mitra tujuan pelaporan dalam program AEoI (DJP, 2020). Adanya program AeoI dalam tataran global dapat mengurangi kemungkinan wajib pajak melakukan tax evasion (OECD, 2018). AeoI sebagai program yang hampir sama dengan Foreign Account Tax Compliance Act (selanjutnya disebut FACTA), yaitu adanya keterbukaan informasi keuangan terkait pajak yang dilakukan secara berkala, otomatis, dan menyeluruh, memiliki potensi yang besar dalam meningkatkan penerimaan pajak suatu negara. AEoI dinilai memiliki cakupan yang lebih luas karena meliputi seluruh warga negara asing yang memiliki atau menyembunyikan harta di satu negara. AEoI juga tidak memiliki jumlah minimum dalam pelaporan harta, sedangkan FATCA memiliki jumlah minimum sebesar USD 50.000. AeoI merupakan perluasan dari FACTA yang hanya sebatas identifikasi harta menjadi program yang mencegah adanya pencucian uang (Panayi, 2016). Cakupan yang luas pada AeoI membuat lembaga keuangan memiliki beban operasional yang semakin berat karena informasi yang harus dilaporkan dalam AeoI akan lebih banyak AEoI ini merupakan standard baru dalam tataran global dalam hal menjawab tatangan perkembangan zaman untuk mengurangi kemungkinan penggelapan pajak. Pertukaran infromasi keuangan dapat dilakukan dengan negara yang berpartisipasi dan menerapkan AEoI dengan mengirimkan serta dapat menerima informasi yang disepakati sebelumnya tanpa harus mengirim permintaan khusus (OECD, 2017).

AEoI juga dianggap oleh OECD (2017) dapat menemukan atau mendekteksi penggelapan pajak yang dilakukan oleh wajib pajak yang sebelumnya sulit untuk dilakukan. Hal ini dapat membantu pemerintah untuk meningkatkan pendapatan pajak yang hilang dari wajib pajak yang tidak patuh. Selain itu, AEoI akan memperkuat hubungan antar negara dalam tataran internasional untuk meningkatkan transparansi, kerja sama, dan akuntabilitas antara lembaga keuangan dan otoritas pajak. AEoI juga memiliki manfaat yang secara tidak langsung akan mengungkap asset yang disembunyikan oleh wajib pajak secara sukarela, sehingga melaporkan semua informasi keuangan atau kekayaan yang dimiliki wajib pajak tersebut. AEoI dan Exchange of Information on Request (selanjutnya disebut EoIR) -merupakan sistem yang sudah ada sebelumnya terdapat dalam tax treaty setiap negara yang memiliki kerjasama- akan saling melengkapi untuk meningkatkan efektivitas upaya otoritas pajak dalam menangani penggelapan pajak.

\section{STANDAR PELAPORAN UMUM}

Standar Pelaporan Umum ini dikenal Common Reporting Standard (selanjutnya disebut CRS) telah diatur oleh OECD dalam Standard for Automatic Exchange of Financial Account Information in Tax Matters sebagai panduan untuk negara-negara yang mengikuti pertukaran informasi secara otomatis. Indonesia dalam hal ini menyebutkan 
dengan jelas terkait dengan CRS pada PMK No.19/2018 Pasal 1 Angka 3 yang menyatakan CRS adalah standar yang berisi pelaporan, prosedur identifikasi Rekening Keuangan, dan Pertukaran Informasi yang dirujuk atau diatur dalam Perjanjian Internasional untuk melakukan Pertukaran Informasi antar negara (DGT, 2018).

\section{METODOLOGI}

Dalam penelitian ini, sumber informasi data primer didapatkan melalui studi lapangan, yaitu wawancara mandalam. Wawancara mendalam dilakukan dengan para informan yang berkaitan dengan penelitian, di antaranya Direktorat Jenderal Pajak, The Japanese National Tax Agency serta akademisi dari berbagai Universitas di Jepang. Para informan diberikan kebebasan dalam menjawab pertanyaan sesuai dengan pendapatnya karena peneliti tidak membatasi jawaban informan. Sumber informasi data sekunder dalam penelitian ini diperoleh melalui studi literatur atau kepustakaan, seperti buku, jurnal, peraturan perundang-undangan, karya ilmiah seperti skripsi dan tesis maupun data sejenis lainnya yang diperoleh dari internet yang berkaitan dengan penelitian.

Penelitian ini menggunakan teknik analisis data kualitatif. Data yang diperoleh melalui studi lapangan selanjutnya dilakukan pengkodean hingga menghasilkan konsep yang berkaitan dengan penelitian. Konsep yang dihasilkan tadi kemudian dianalisis.

\section{DISCUSSION}

\section{Evaluasi Automatic Exchange of Information dalam Pemeriksaan Pajak di Indonesia}

Indonesia menjadi salah satu negara yang ikut serta dalam perjanjian internasional terkait pertukaran informasi secara otomatis (Automatic Exchange of Information) pada bulan September tahun 2018. Indonesia menunjukan komitmen awalnya terhadap AEoI ini diawali dengan membuat sebuah produk hukum sebagai payung hukum diimplementasikan AEoI serta menunjukkan bahwa Indonesia patuh atau serius untuk mengikuti AEoI ini. Produk hukum yang pertama kali dikeluarkan itu adalah Peraturan Pemerintah Pengganti Undang-Undang Nomor 1 Tahun 2017 Tentang Akses Informasi Keuangan Untuk Kepentingan Perpajakan (selanjutnya disebut Perppu No.1/2017) yang kemudian ditetapkan mejadi undang-undang melalui Undang-Undang Nomor 9 Tahun 2017 tentang Penetapan Peraturan Pemerintah Pengganti Undang-Undang Nomor 1 Tahun 2017 Tentang Akses Informasi Keuangan Untuk Kepentingan Perpajakan Menjadi Undang-Undang (selanjutnya disebut UU No.9/2017), peraturan ini mulai berlaku pada 23 Agustus 2017. Dasar hukum yang telah dibuat dan persyaratan lainnya dari OECD telah terpenuhi, Indonesia sudah mulai mengimplementasikan AEoI pada tahun 2018, artinya Indonesia telah mengimplementasikan AEoI selama 3 tahun, dan Indonesia berkomitmen penuh didalam proses AEoI.

Regulasi terkait AEoI berada di direktorat perpajakan internasional untuk bagian perpajakan internasional, sistem teknologi informasi berada dibawah Direktorat TIK, sedangkan pengolahan data berada di Direktorat Data Informasi Perpajakan. Didalam melalukan implementasi AEoI menggunakan suatu Prosedur identifikasi yang telah diatur dalam Common Reporting Standard (selanjutnya disebut CRS), pada tahap ini CRS sudah mengatur secara mendetail untuk mengidentifikasi Rekening Keuangan yang dilaporkan atau tidak dilaporkan.

Keikutsertaan Indonesia didalam pertukaran informasi secara dilakukan dalam rangka mencegah penghindaran pajak, mencegah pengelakan pajak, mencegah penyalahgunaan perjanjian pajak berganda oleh pihak-pihak yang tidak berwenang dan mendapatkan informasi terkait pemenuhan pajak kewajiban wajib pajak. AEoI juga 
dilakukan dalam rangka transparasi informasi, hal ini dikarenakan sebelum adanya AEoI, data informasi keuangan nasabah masih bersifat rahasia dan tidak mudah didapatkan oleh kantor pajak. Proses pertukaran informasi dapat bersifat resiprokal melalui permintaan informasi berdasarkan permintaan, pertukaran informasi secara spontan dan pertukaran informasi secara otomatis (Automatic Exchange of Information). Pada pertukaran informasi secara otomatis informasi yang dipertukarkan bersifat periodik, sistematis dan berkesinambungan antara penjabat yang berwenang di Indonesia dengan Penjabat di negara yuridksi mitra.

Didalam proses pertukaran informasi secara otomatis terdapat informasi yang dipertukarkan dengan negara mitra yakni:

1. Informasi terkait pemotongan pajak atas penghasilan yang dibayarkan kepada subjek pajak Indonesia atau Negara/Yuridiksi Mitra.

2. Informasi keuangan Nasabah Asing.

3. Informasi laporan per negara

Informasi perpajakan lainnya berdasarkan kesepakatan bersama antara Indonesia dan Negara Mitra atau Yurisdiksi mitra.

Ketersediaan informasi atau data pada implementasi AEoI ini tentu menjadi hal yang paling penting ketidakadaan informasi atau data tentu menyebabkan AEoI tidak bisa dilaksanakan karena data tersebut yang nantinya akan dipertukarkan dengan negara atau yurisdiksi lain. Apabila tidak terjadi pertukaran, Indonesia tidak mendapatkan data WNI yang dimiliki oleh yurisdiksi lain. Oleh karena itu, sumber daya data ini penting agar implementasi AEoI dapat efektif berjalan. Informasi data yang dimiliki dan telah dilaporkan oleh Lembaga Keuangan menjadi sumber daya data yang penting bagi DJP, sehingga data yang telah dimiliki dapat dikirimkan sesuai dengan perjanjian internasional. Pihak DJP pun juga akan menerima data yang kemudian diolah untuk dimanfaatkan dalam mengoptimalkan potensi penerimaan pajak.

Ketersediaan data bersumber dari pelaporan oleh Lembaga Keuangan sebagai penyedia informasi keuangan, sampai dengan tahun 2020 telah terdapat sekitar 8000 lembaga keuangan makro dan mikro yang ikut serta didalam pelaporan data transaksi keuangan milik nasabahnya. Lembaga Keuangan sudah melakukan pelaporan sesuai ketentuan peraturan dan melaporkan dalam batas waktu yang diminta oleh DJP. Lembaga Keuangan juga menunjukan sifat kooperatifnya dengan melakukan pelaporan pada setiap tahunnya, yakni 2018, 2019, dan 2020. Sejak awal pengimplementasian AEoI proses komunikasi memang telah dilakukan antara DJP dengan lembaga Keuangan sehingga setiap lembaga keuangan sudah menerima informasi yang diperlukan terkait dengan implementasi kebijakan AEoI.

Selain proses komunikasi, sosialiasi secara masif juga dilakukan dengan lembaga keuangan makro dan mikro baik mencakup teknis pelaporan maupun regulasi-regulasi terkait pelaporan data transaksi keuangan, aturan teknis mengenai petunjuk teknis juga tersedia di website milik kantor pajak. Proses sosialiasi biasanya dilakukan pada saat menjelang waktu pelaporan dibulan maret untuk lembaga keuangan yang melalui portal AEoI, namun untuk yang melalui sistem SISPINA dilakukan dibulan juni sampai juli, pada tahun ketiga proses sosialiasi sudah lebih jarang dilakukan karena lembaga keuangan sudah memahami proses pelaporan data keuangan nasabah, dalam mendukung proses sosialisasi proses pendampingan juga diberikan terhadap lembaga keuangan yang masih mengalami masalah didalam pelaporan data keuangan nasabahnya. Selain dengan lembaga keuangan, kerjasama juga dilakukan dengan OJK (otoritas jasa keuangan). Kewenangan yang dimiliki DJP hanya digunakan untuk akses informasi keuangan dalam kepentingan perpajakan. Pada kewenangan yang dimiliki oleh DJP dalam proses evaluasi ini sudah cukup baik dan diatur secara detail dalam berbagai aspek yang ada dalam AEoI, 
seperti prosedur identifikasi yang dilakukan oleh Lembaga Keuangan dan sanksi apabila terdapat masalah bagi Lembaga Keuangan atau nasabah WNA tidak mau melaporkan informasi keuangan kepada DJP.

Proses pelaporan transaksi keuangan oleh lembaga keuangan kepada DJP menggunakan suatu sistem SIPINA (Sistem Informasi Penyampaian Nasabah Asing), sistem ini digunakan untuk Lembaga Keuangan yang diawasi oleh Otoritas Jasa Keuangan secara langsung seperti bank, asuransi, dan pasar modal. Sedangkan untuk Lembaga Keuangan selain dari yang disebutkan langsung seperti lembaga keuangan mikro, fintech dan koperasi melakukan pelaporan melalui sistem DJP yakni portal AEOI. Kantor pajak memiliki akses untuk masuk kedalam sistem yang digunakan oleh lembaga keuangan dan terhubung langsung dengan sistem DJP. Penggunaan sistem sebagai penunjang implementasi kebijakan AEoI dipengaruhi oleh teknologi terkait sistem yang dimiliki oleh DJP untuk melakukan pertukaran dan menerima data dari Lembaga Keuangan ataupun yurisdiksi lain. Sumber daya sistem ini penting mengingat menjadi salah satu yang perlu disiapkan oleh Indonesia didalam mengimplementasi AEoI adalah Indonesia perlu menyiapkan ketersediaan sistem transmisi data yang dapat memfasilitasi pengiriman data dari Lembaga Keuangan ke DJP serta dari DJP kepada negara atau yurisdiksi mitra dan sebaliknya.

Sistem informasi untuk pertukaran data secara otomatis telah dibangun secara internal oleh DJP sebelum dimulainya AEoI pada tahun 2018, pada tahun pertama implementasi sistem terdapat kendala dikarenakan adanya traffic data dan validasi data, di tahun kedua masih ada yang dilakukan secara manual pada saat validasi namun ditahun ketiga pelaporan sistem sudah berjalan lancar. Berdasarkan hal tersebut, dapat dilihat bahwa evaluasi sistem yang dimiliki oleh DJP sudah berjalan dengan baik. Sistem yang sudah baik juga sudah dirasakan oleh pihak Lembaga Keuangan yang sudah tidak mengalami kendala dalam pelaporan nasabah WNA. Hal ini terjadi karena DJP memiliki dua sistem dalam pelaporan, yaitu sistem dari DJP dan sistem yang berkoordinasi dengan pihak OJK, sehingga tidak ada penumpukan pelaporan informasi keuangan yang dilakukan oleh Lembaga Keuangan. Sistem yang digunakan oleh DJP telah memenuhi standar internasional yang telah ditetapkan global forum dan memiliki kerahasiaan penuh terhadap data wajib pajak.

Selain sistem pendukung, kemampuan dan kapasitas SDM DJP juga menjadi hal yang sanggat penting, kemampuan SDM tidak terbatas pada penguasaan terkait aturan AEoI namun juga hubungan DJP dengan para stakeholders, yaitu Lembaga Keuangan, Otoritas Jasa Keuangan (selanjutnya disebut OJK), dan nasabah WNA secara tidak langsung.Kemampuan Sumber daya manusia didalam melakukan analisa data yang diterima oleh DJP melalui proses pengolahan data dan proses validasi, sehingga kesamaan data dari data yang diterima dengan data DJP yang dimiliki dapat dilakukan tingkat selanjutnya digunakan pada proses mapping dalam rangka mengidentifikasi Wajib Pajak yang memiliki risiko tinggi dan dilanjutkan dengan tindakan law enforcement. Proses pengolahan data menjadi penting hal ini untuk menghindarkan salah sasaran dalam melakukan law enforcement kepada Wajib Pajak karena dapat berpengaruh kepada kepercayaan masyarakat kepada DJP sehingga berdampak kepada implementasi AEoI itu sendiri. Proses analisis data dan pencocokan informasi serta validasi dilakukan oleh direktorat data informasi perpajakan.

Sampai dengan tahun 2020, AEoI di Indonesia telah terjadi pertukaran informasi sebanyak 2 (dua) kali dengan negara lain. Negara-negara yang sudah melakukan pertukaran informasi keuangan dengan Indonesia terbagi menjadi dua kategori, yaitu Negara Partisipan dan Negara Tujuan Pelaporan. Negara Partisipan diartikan sebagai negara-negara yang memiliki perjanjian internasional dengan Indonesia untuk melakukan 
pertukaran, sedangkan untuk Negara Tujuan Pelaporan adalah negara yang harus dikirimkan datanya oleh otorias pajak Indonesia. Data yang diterima pada tahun pertama sudah cukup banyak yakni terdapat 103 Negara Partisipan dan 85 Negara Tujuan Pelaporan (DGT, 2020).

Data yang diterima pada tahun pertama terjadi pertukaran informasi, yakni September 2018, sudah diolah oleh DJP bahkan sudah didistribusikan ke Kantor Pelayanan Pajak (KPP) untuk ditindaklanjuti dalam bentuk penggalian potensi pajak. Sedangkan, data informasi keuangan yang diperoleh pada tahun kedua implementasi AEoI, yakni september 2019, sudah dilakukan proses identifikasi untuk melakukan matching data dengan database yang dimiliki oleh DJP. Proses identifikasi ini dilakukan dengan mencocokan identitas data, identitas data dilihat dari beberapa layer untuk dicocokan, layer pertama yang digunakan DJP adalah nama dan alamat. Apabila pada layer pertama sudah cocok maka dapat dikatakan bahwa data tersebut valid. Akan tetapi, jika tidak cocok akan ditentukan pada layer berikutnya. Layer kedua adalah NPWP atau TIN sebagai penentu data yang diberikan valid atau tidak. Oleh karena itu, kegunaan layer dalam proses matching data untuk mengatisipasi apabila Negara Partisipan tidak mengirimkan datanya secara lengkap. Ketika semua layer sudah digunakan dan tidak ada yang matching dengan database DJP, maka DJP dapat meminta ulang kepada Negara Partisipan yang tidak mengirimkan datanya secara lengkap. Setelah semua data sudah dilakukan proses matching dan dicek validitasnya, data tersebut akan dipetakan kembali, seperti data pertukaran agar dapat didistribusikan ke KPP sehingga dapat dilakukan analisis untuk tindakan selanjutnya.

Data hasil pertukaran informasi secara otomatis dapat digunakan untuk memperkuat proses pemeriksaan pajak. Pemeriksaan kepada wajib pajak dilakukan dalam rangka mendorong pertumbuhan penerimaan pajak yang berkelanjutan, meningkatkan kepatuhan Wajib Pajak yang berkelanjutan (sustainable compliance), mencegah praktik penghindaran pajak oleh Wajib Pajak. Peningkatan kualitas dan kuantitas pemeriksaan pajak penting dalam rangka menjaring penggalian potensi pajak.

Ruang lingkup pemeriksaan terdiri dari pemeriksaan untuk satu jenis pajak maupun untuk seluruh jenis pajak. Sedangkan kriteria pemeriksaan berisi alasan wajib pajak dikenakan pemeriksaan, yakni:

1. Pemeriksaan Rutin, merupakan pemeriksaan yang dilakukan sehubungan dengan pemenuhan hak dan/atau pelaksanaan kewajiban perpajakan Wajib Pajak.

2. Pemeriksaan Khusus, meliputi: Pemeriksaan khusus berdasarkan keterangan lain berupa data konkret (audit based on data), merupakan pemeriksaan yang dilakukan terhadap Wajib Pajak yang berdasarkan keterangan lain berupa data konkret menunjukkan adanya indikasi ketidakpatuhan pemenuhan kewajiban perpajakan; dan Pemeriksaan khusus berdasarkan analisis risiko (risk-based audit), merupakan pemeriksaan yang dilakukan terhadap Wajib Pajak yang berdasarkan hasil analisis risiko menunjukkan adanya indikasi ketidakpatuhan pemenuhan kewajiban perpajakan.

Penentuan wajib pajak yang akan diperiksa berdasarkan parameter jika terdapat indikasi ketidakpatuhan oleh wajib pajak, adanya modus yang dilakukan oleh wajib pajak, terdapatnya potensi pajak dan kemampuan ekonomis wajib pajak untuk membayar. Data informasi keuangan yang didapatkan dari AEoI dapat digunakan untuk menunjang proses pemeriksaan jika di indikasikan tidak seluruh penghasilan wajib pajak dilaporkan didalam SPT (surat pemberitahuan), sebagai data pendukung dan penguat proses pemeriksaan, maupun data sebagai penggalian potensi pajak. Data transaksi keuangan yang didapatkan dari divisi direktorat informasi perpajakan dikirimkan kepada KPP-KPP setempat untuk digunakan oleh AR, pemeriksa pajak dalam proses pemeriksaan dan juru sita pajak untuk kepentingan blokir. Dengan adanya AEoI pemeriksa pajak tidak perlu lagi melakukan 
pemeriksaan secara acak namun bisa langsung dilakukan pemeriksaan secara langsung terhadap wajib pajak yang diindikasikan melakukan penghindaran pajak.

Pemeriksa pajak di DJP sudah menggunakan data AEoI, jika terdapat data yang kurang lengkap dari lembaga keuangan maka akan dilakukan validasi berupa permintaan data ulang kepada wajib pajak. Proses pemeriksaan di DJP dengan menggunakan data CRM sebagai pengganti CRS menggunakan sistem digitaliasi berupa aplikasi untuk mempermudah proses pemeriksaan dan mempersingkat waktu. Data AEoI digunakan untuk penggalian potensi pajak yang saat ini belum maksimal. Pemeriksa pajak sudah memiliki kemampuan untuk mengolah data transaksi keuangan secara otomatis, proses ujicoba untuk mengolah data, mengkonfirmasi, analsis data sudah dilakukan sejak tahun 2019 dan di tahun 2020 data AEoI telah digunakan di seluruh KPP di indonesia, pemberian pelatihan dilakukan terhadap pemeriksa dilakukan secara reguler dan spesifik tidak hanya menganalisis data namun pengolahan data, dan membaca dan menterjemahkan data keuangan secara keseluruhan untuk memilih data yang akan digunakan dalam proses pemeriksaan.

\section{Evaluasi Automatic Exchange of Information dalam Pemeriksaan Pajak di Jepang}

Pemeriksaan pajak di jepang dilakukan secara rutin pertiga tahun sekali. Mereka mempunya suatu sistem dan cascade dalam menentukan wajib pajak yang akan dilakukan pemeriksaan. Target wajib pajak yang akan dilakukan pemeriksaan ditetapkan oleh kepala audit pajak kantor pajak setempat (Disctrict Tax Offices) ataupun kantor pajak pusat (Regional Taxation Bureaus). Secara struktur kelembagaan organisasi pajak di Jepang terdapat pemisahan antara bagian yang bertugas untuk pengumpulan pajak, melakukan administrasi perpajakan dan melakukan pemeriksaan pajak. Kantor-Kantor pajak di jepang tersebar di berbagai provinsi serta kota-kota yang ada di Jepang. Dalam proses pemeriksaan pajak kantor pajak terbagi menjadi beberapa divisi yakni:

1. Individual Tax Groups and Corporate Tax Groups in Districts Tax Offices.

2. Information and Examination Groups in Taxation Dept. Of Regional Taxation Bureaus (RTBs).

3. Examination Groups of Large Enterprise Examination Dept.

Penentuan wajib pajak yang akan diperiksa oleh masing-masing divisi kantor pajak dengan mempertimbangkan beberapa faktor diantaranya:

1. Besar kecilnya skala perusahaan dan jumlah kepemilikan asset individu ( HNWI), Pembayar pajak di Jepang baik individu maupun perusahaan di kategorisasi kedalam tingkatan dengan mempertimbangkan faktor-faktor keuangan diantaranya (jumlah penjualan, jumlah keuntungan, jumlah modal, dll).

2. Catatan audit wajib pajak sebelumnya dalam hal mengetahui resiko kepatuhan dan kompleksitas bisnis wajib pajak serta tingkat kepatuhan dari wajib pajak.

3. Profit margin dibandingkan dengan perusahaan sejenis untuk mendapatkan data keuangan pembanding dari wajib pajak lainnya.

4. Informasi dari publik, media ataupun dari kantor pajak setempat dilokasi yang berbeda.

Pelaksanaan pemeriksaan pajak mengacu pada tahun buku yang dimulai setiap bulan Juli untuk tahun buku yang dimulai pada 1 Juli sampai 30 Juni untuk tahun pajak berjalan. Didalam proses analisis KSK atau sistem pengolahan data dan informasi juga digunakan dalam membantu kepala audit pajak untuk menentukan target wajib pajak yang akan diperiksa. Peningkatan jumlah wajib pajak yang diperiksa di jepang menurun dalam beberapa tahun sejak dilakukannya reformasi perpajakan, hal ini juga berakibat dengan menurunnya Audit Coverage Ratio yang membandingkan rasio jumlah wajib pajak diperiksa terhadap total wajib pajak terdaftar.

Sebagai bagian dari proses pemeriksaan, proses investigasi terhadap wajib pajak 
digunakan saat terjadinya kasus dibidang perpajakan. Proses investigasi dijepang memiliki hambatan dalam hal wajib pajak tidak menyetujui jadwal pemeriksaan pajak yang ditetapkan oleh kantor pajak. Berdasarkan Undang-Undang No.66 tahun 1962 yang diperbaharui pada tahun 2011, pemeriksa pajak dalam menjalankan proses pemeriksaan pajak wajib mendapatkan persetujuan dari wajib pajak dan wajib pajak yang akan diperiksa mendapatkan hak untuk melakukan penjadwalan ulang dengan alasan yang dapat diterima.

Di dalam Undang-Undang tahun tersebut juga memuat ketentuan bagi pemeriksa pajak untuk menjelaskan hasil pemeriksaan pajak pada saat proses pemeriksaan telah selesai dilakukan, dalam kondisi wajib pajak menolak hasil pemeriksaan implikasinya pemeriksa pajak membutuhkan waktu untuk menjelaskan kembali proses pemeriksaan yang telah dilakukan termasuk jika wajib pajak mengajukan keberatan terhadap hasil pemeriksaan pajak ke pengadilan pajak. Hambatan lainnya adalah tidak terdaftarnya wajib pajak sebagai suatu entitas bisnis dan tidak melakukan pelaporan kewajiban pajak sehingga menyulitkan pemeriksa pajak untuk mengindentifikasi wajib pajak tersebut. Sedangkan hambatan yang ketiga didalam proses pemeriksaan adalah sulitnya kantor pajak jepang untuk mendapatkan informasi pajak terkait transaksi lintas batas negara (cross border transaction), hambatan ini yang kemudian mendasari pemerintah jepang untuk ikut serta didalam kesepakatan pertukaran informasi antar negara dibidang perpajakan.

Komitmen pemerintah Jepang didalam transparansi dan kerjasama dibidang perpajakan dalam rangka pertukaran informasi keuangan secara otomatis (AEoI) dilakukan melalui mekanisme penerapan pertukaran informasi melalui common reporting standard (CRS) yakni pertukaran otomatis informasi keuangan berdasarkan standar pelaporan umum dan pertukaran laporan per negara (Country by Country Report/CbCR). Terdapat tiga lembaga yang memberikan persetujuan mengenai penerapan AEoI di Jepang. Ketentuan dalam pelaksanaan AEoI diatur berdasarkan undang-undang yang mulai berlaku pada 1 Januari 2017, dan laporan pertama akan disampaikan oleh lembaga keuangan pelapor paling lambat 30 April 2018, AEoI digunakan dalam rangka menghindari transaksi penghindaran pajak internasional dengan meningkatkan keterbukaan lembaga keuangan dimana sebelumnya terdapat keterbatasan bagi kantor pajak untuk mendapatkan informasi keuangan dari lembaga keuangan, selain itu AEOI sanggat bermanfaat untuk pemerintah jepang terutama untuk mendapatkan data mengenai penduduk dan foreign people yang ada di jepang serta mengetahui asset wajib pajak jepang yg berinvestasi di luar negri serta memberikan manfaat bagi kantor pajak Jepang dalam rangka mendapatkan informasi tambahan dari negara lain dan dapat digunakan dalam rangka mendapatkan data mengenai kepatuhan wajib pajak.

Pemerintah Jepang melalui kantor pajaknya yakni National Tax Agency memiliki sejarah yang panjang didalam penerapan AEoI, sebelum AEoI diimplementasikan Pemerintah Jepang sudah menggunakan CRS (Common Reporting Standard) didalam pertukaran data dengan negara lain. Sistem ini berhasil dalam rangka membantu proses pemeriksaan perpajakan, sistem ini membantu kantor pajak Jepang untuk mendapatkan data ketika terdapat wajib pajak yang tidak melaporkan kepemilikan assetnya di lembaga keuangan negara lain. Sedangkan sistem CbCR digunakan dalam rangka menghindari terjadinya transfer pricing yakni upaya penghindaran pajak melalui transaksi yang terjadi antara perusahaan-perusahaan multinasional yang tergabung dalam suatu grup usaha yang berkedudukan dinegara yang berbeda, CbCR merupakan suatu sistem yang sanggat efektif didalam mencegah terjadinya praktik penghindaran pajak karena hubungan istimewa. Melalui CbCR kantor pajak mendapatkan informasi perpajakan yang akan membantu otoritas untuk menganalisis suatu transaksi perpajakan. Dalam rangka pertukaran data dan 
proses transmisi data keuangan pemerintah jepang menggunakan sistem $e$-Tax system. ETax system adalah suatu sistem yang didalamnya berisi fitur-fitur perpajakan yang dapat digunakan oleh wajib pajak dalam rangka pelaporan pajak, pengajuan permohonan pengembalian kelebihan pembayaran pajak, pembayaran pajak dan prosedur-prosedur pemenuhan kewajiban perpajakan lainnya.

Selain untuk pelaporan kewajiban perpajakan rutin, e-Tax system digunakan untuk pelaporan data transaksi keuangan otomatis (CRS), cara penggunaan sistem ini tersedia di website NTA dan sebelumnya telah diberikan sosialisasi kepada para pengguna, saat ini pemerintah jepang sudah menggunakan CRS dengan format terbaru. Data dan informasi yang dapatkan dari pertukaran informasi dengan lembaga keuangan internasional disimpan dan diproses oleh kantor pajak jepang didalam KSK (Kokuzei Sogo Kanri) atau sistem Administrasi Pajak Komprehensif, sebagai pelengkap dari sistem ini dikembangkan pula Wide Area Network sebagai suatu sistem pengembangan dalam rangka pengembangan sistem administrasi perpajakan secara elektronik. Data yang tersimpan kemudian dilakukan proses analisis dan digunakan untuk membantu proses pemeriksaan wajib pajak. Big data analysis merupakan hal yang paling penting didalam rangka menyaring informasi dan matching data, hal dilakukan untuk menyaring informasi karena data yang diperoleh kantor pajak jepang melalui pertukaran informasi keuangan jumlahnya sanggat besar, data dan informasi yang didapatkan antara lain informasi mengenai penghasilan, bunga, deviden, dan asuransi.

Didalam mendapatkan data transaksi yang bersumber dari instusi lain seperti lembaga pemerintah, lembaga keuangan dan institusi lainnya kantor pajak jepang memiliki otoritas penuh. Kantor pajak jepang yakni NTA dapat mengajukan permohonan kepada lembagalembaga terkait seperti lembaga keuangan untuk menyediakan informasi yang dibutuhkan, hal ini didukung oleh kewenangan dan regulasi penuh yang dimiliki oleh kantor pajak. Lembaga keuangan di jepang sanggat patuh terhadap ketentuan perpajakan hal ini dikarenakan pelanggaran terhadap ketentuan perpajakan akan dikenakan sanksi yang berat tidak hanya berupa sanksi denda administrasi namun juga sanksi pidana dan terdapat sanksi terhadap lembaga keuangan yang tidak memberikan informasi dan data keuangan yang dibutuhkan oleh kantor pajak. Dalam hal AEoI petugas pajak memperoleh laporan informasi tentang akun keuangan penduduk dan bukan penduduk (baik individu maupun entitas) dari lembaga keuangan yang berlokasi di setiap yurisdiksi berdasarkan ketentuan pertukaran informasi yang ditetapkan dalam perjanjian pajak dan secara otomatis dipertukarkan di antara administrasi pajak di setiap yurisdiksi, selain itu lembaga keuangan wajib melaporkan informasi rekening keuangan dan rekening penyimpanan. Selain lembaga keuangan berdasarkan regulasi perpajakan AGRNT pasal 74 ayat 2 tahun 2019, NTA juga mendapatkan otoritas untuk mendapatkan data keuangan dari organisasi lain non lembaga keuangan.

Sejak diimplementasikan di tahun 2017, penerapan AEoI dijepang dapat dikatakan berhasil. Dengan adanya AEOI wajib pajak di jepang akan berupaya untuk melaporkan setiap penghasilan dan harta yang dimiliki dan bersumber dari negara lain. Keberhasilan penerapan AEoI didukung pula oleh karaktersitik wajib pajak di Jepang dimana tingkat kepatuhan wajib pajak di jepang sanggat tinggi hal ini dikarenakan pendidikan moral dan pengetahuan mengenai pajak sudah masuk di dalam kurikulum pendidikan di jepang sejak di sekolah dasar,sehingga pemahaman akan pajak sudah timbul sejak dini, disamping itu ada kepercayaan yang sanggat tinggi terhadap petugas pajak di Jepang. Penggunaan sistem identitas nasional dengan satu nomer juga membantu dalam meningkatkan database perpajakan sehingga tidak terdapat identitas ganda. Dalam hal pemenuhan kewajiban perpajakan mayoritas wajib pajak di jepang menggunakan jasa konsultan pajak yang membantu kewajiban perpajakan mereka. Ada empat hal mendasar yang membantu 
keberhasilan penerapan AEoI yakni sumber daya manusia di kantor pajak, teknologi dan proses sosialisasi.

Terkait dengan impelmentasi masih terdapat tantangan didalam penerapan AEoI permasalahan yang timbul adalah masih terdapatnya negara yang tidak ikut didalam penerapan AEoI dan tidak melakukan pertukaran informasi keuangan secara otomatis sehingga sulit untuk mendapatkan informasi data keuangan wajib pajak yang ditempatkan dinegara tersebut sehingga kedepannya diharapkan semakin banyak negara yang ikut didalam kesepakatan AEoI. Dari sisi kelembagaan otoritas pajak terdapat kelemahan dimana para pegawai kantor pajak di Jepang kebanyakan sudah berusia lanjut dan tidak terdapat penambahan jumlah pemeriksa pajak dalam kurun waktu beberapa tahun sehingga National Personal Authorities Jepang perlu meningkatkan jumlah pegawai pemeriksa pajak.

\section{DAFTAR PUSTAKA}

Darussalam \& Septriadi, Danny. (2017). Perjanjian Penghindaran Pajak Berganda ( $2^{\text {nd }}$ ed.) Jakarta: DDTC (PT Dimensi Internasional Tax).

Directorate General of Taxes. (2018) Frequently Asked Questions Common Reporting Standard (CRS). Jakarta: Directorate General of Taxes.

Directorate General of Taxes. (2020) Exchange of Information. Jakarta: Directorate General of Taxes. Edwards III, George C. (1980). Public Policy Implementation. Washington DC: Congressional Quarterly Press.

Santoso, Iman \& Rahayu, Ning. (2019). Corporate Tax Management (revised ed.). Jakarta: Ortax.

Gadzo, Stjepan \& Klemencic, Irena. (2017). Effective International Exchange as a Key Element of Modern Tax Systems: Promises and Pitfalls of The OECD's Common Reporting Standard. Review Article of University of Rijka.

Meinzer, Markus. (2017). Automatic Exchange of Information as The New Global Standard: The End of (Offshore Tax Evasion) History. Journal of Munich Personal RePEc Archive. 